\title{
多軸負荷を受ける多結晶形状記憶合金
}

\author{
徳 田 正 孝* ペトロ・シットネル** \\ Polycrystalline Shape Memory Alloy under \\ Multi-Axial Loading Conditions
}

by

\author{
Masataka ToKUdA* and Petro SitTNER**
}

\begin{abstract}
Key words : Stress-induced phase transformation, Pseudoelastic effect, Systematic experiments, Thin-walled tube, Constitutive equations, Meso-mechanics, Intelligent material
\end{abstract}

1 は じめに

近年, 機械工学の研究分野において, 材料の相変態に かかわる研究が活発である，これまで，材料の相変態は 機械工学の分野の研究者・技術者にとって必須の知識で はあっても主たる研究対象ではなかった。

ただし，別の側面からは，相変態は古くから機械工学 と深くかかわっている，例えば，液体・気体間の相変態 は蒸気機関の原理であり, 機械工学分野の研究者・技術 者にはなじみが深い.この蒸気機関で利用される材料 （物質）特性は, 気体と液体間の体積比，さらにこれを ある一定の容積内に制限した時に生じる大きな圧力差で ある．これは，本論文で議論する形状記憶効果応用技術 の一種であると分類することもできるであろう.

相変態を機械工学にかかわる材料学的視点から，ある いは材料力学的視点から眺めるとどうであろうか. 機械 工学において，材料は長く提供されるものであった．提 供された材料の力学的特性を把握し, これを基礎にして, 安全あるいは寿命の長い機械・構造物を合理的に設計す るのである．機械工学における材料研究は，提供された 材料の力学的特性 (変形・強度特性) を構成方程式に集 約することであり，これを用いて機械・構造物の応力・ ひずみ解析を行い，その安全性を確認した. もちろん， 計算機の発達の十分でない時代においては，このような いわゆる構造解析は実際には容易ではなく，多くの工学 技術者の興味を集めた大きな研究対象の一つであった. この構造解析における多くの障害を一挙に取り除いたの が計算機の発達に助けられた汎用数值解析法（とくに有 限要素法）の発達・普及である。ここにおいて，機械・ 構造物の応力・ひずみ解析手法開発に忙殺されていた材 料力学分野の研究者はようやく, 材料の力学特性の解明 に目を向ける余裕が出てきた. さらに，複合材料の出現 がある. 必要な力学特性を持つ材料を設計・製作するこ とが, 機械工学の材料力学分野の役割として入ってきた. とくに, 纎維強化材料 (GFRP, CFRP, FRM, C/C など）の発達には目覚ましいものがあり，これを契機に
必要な力学特性を人為的にコントロール（設計）するテ イラード・マテリアルの概念が構築された.

さて，このように必要な特性を持つ材料は，設計する ものである，あるいはその可能性があるとの考えが定着 した結果，粒子分散強化型複合材料，また傾斜機能材料 などの新素材開発研究が, 機械技術者の興味を引く研究 分野ともなり，さらには，インテリジェント材料（知能 材料，スマート材料）設計の概念にまで到達する.イン テリジェント材料とは, 生物・生体，あるいは生体組織 のように，危険に対するセンサー機能を持ち，かつその 危険の度合いを判断する (自己診断)，ささらにそれに対 する自己反応（危険に対する回避，あるいは損傷が生じ た場合の自己修復）などの機能を持つ理想（夢）の材料 である.ここにおいて，材料（マテリアル）とこれらの 組み合わせにより得られる機械・構造物（システム）と の区別が判然としなくなる．これは，材料の特性がどの ような微視的構造・微視的メカニズムで発現しているか を考える時，もともと当然のことである．すなわち我々 が工業的に利用している多くの金属材料は，原子，分子， 結晶, 多結晶といった階層構造を持っている. 同じ原子 よりなっている材料でもそれぞれの階層での構造の違い により全く異なる力学的特性を持つ材料ができ上がる。 例えば炭素棒とダイアモンドの違いである．また，各階 層構造における久陷が材料の（力学的）特性に決定的な 役割を果たす．例えば，結晶構造における転位，あるい はクラックの存在である．もし転位なる線欠陥がなけれ ば，その材料の降伏応力は飛躍的に大きくなるであろう し，また微細なクラック（透明なガラスにも目には見え ない微細なクラックが無数に入っている）がなくなれば, 破壊応力は数百倍も大きくなる. このように見る時, 材 料自体も機械・構造物であり，ある機能を実現するため の複雑な構造機能システムである.すなおち, 現在の機 械工学での材料研究は, 材料を構造システムとみる構造 機能解析研究と言えるかもしれない.このような認識は, 電子顕微鏡の発達・普及の助けによるところが大きい.

\footnotetext{
$\dagger$ 原稿受理 平成 7 年 8 月 18 日 Received Aug. 18, 1995

* 正 会 員 三重大学工学部機械工学科 ₹514 津市上浜町, Dept. of Mech. Eng., Mie Univ., Kamihama, Tsu, 514

** チェコ科学アカデミー・物理学研究所, Inst. of Physics, Czech Acad. of Sci., Czech Republic
} 
また，電子計算機による適切な情報処理にも大きく依存 している.

さて，このような材料に対する機械工学分野での材料 設計・システム研究分野の一領域として, 相変態を取り 入れる材料設計・特性評価がある.ここでは, 井上らの 先駆的研究がある.ここでは, 製鉄, 鋳造, 各種熱処理プ ロセスに対して，熱-力学-化学反応を取り入れた形での 材料の力学的特性シミュレーション・システムが完成し ており，そのデモンストレーションとして日本の伝統的 技能・技術である日本刀の熱間鍛造が解析されている.

この相変態に対する関心を，機械工学者・技術者に対 しさらに高めたのが，形状記憶合金 (形状記憶効果) の 出現であろう。すなわち，相変態により材料の力学的特 性が変化するといった金属材料学的なものではなく，相 変態により大きな変形，あるいは大きな力を発生させる ことができるといった極めて運動学的・機械力学的な現 象・効果の出現である.これは，この緒言の初めの部分 にて紹介した液相一固相間変態と基本的に同じ効果であ り，蒸気エンジンに対し，固体エンジンといった新たな 展開なども期待できることになる.

ここで著者らが特に注意を喚起したいのは，以下のよ うなことである．液相一気相変態を支配するのは圧力と 温度である。また，金属の状態図，とくに固相-液相変 態における支配パラメー夕も温度と圧力である。一方, 形状記憶合金の固相-固相変態は, 温度と応力によって 支配される. 応力と圧力の違いは何か. 応力は 2 階のテ ンソルであり 6 つの独立成分を持つ. 圧力（平均静水 圧）はこの 6 つの独立成分の 1 つに過ぎない.もう少し 単純に問題を絞ると，これまでの金属の状態図，あるい は気体-液体状態変化は, 温度軸と圧力軸で表すことが できた. 一方，そのメカニズムから明らかなように固体 一固体相変態はせん断力軸が必要であることを認識する 必要がある.これは, 同じ相変態でも, 固体-固体相変 態の多様性を示唆している，すなわち固体-固体相変態 にその変形原理を持つ形状記憶効果は，せん断応力軸を 含む相変態であり，これまでの圧力軸のみで整理されて いる相変態の力学とは明確に区別して取り扱う必要があ る. 高圧物性物理で有名なブリッジマン教授は, 膨大な 高圧力による材料物性変化に関する論文を発表した後, 今後の研究はせん断応力軸との示唆を残したと言われて いる．これまでの形状記憶合金に関する実験的研究を見 ると，そのほとんどが引張りと温度変化のみによるもの であり，力学的見地からは極めて不十分な状態にある.

現在，このような基礎的実験事実が極めて不足しており， この合金の基礎的研究の発展，さらには形状記憶合金の 工業的応用拡大に対する大きな障害ともなっている.

さてこのような見地に立ち，数年前から著者らの研究 室にてせん断軸を含む一般負荷条件下における多結晶形 状記憶合金の変形挙動を，系統的で，精密な実験により 調べてきた. また，これらに対して，メゾスコピック・ アプローチによる理論的解析研究を進めてきた.

本稿では，上に述べたような見地から多軸複合（一

般）負荷条件下における多結晶形状記憶合金の変形挙動 の研究の状況を総括し，その展望を論じるが，著者らの 研究室以外では殆ど行われていないのが現状である。し たがって, 紹介する内容の多くが著者らの研究グループ のものであり，これまでの研究のまとめのようになって しまうことをお許し願いたい.また，総説ではあるが解 説的な部分も多く含まれてしまうこともご容赦願いたい.

\section{2 一般負荷と形状記憶合金}

緒言では, 固体-固体間相変態, とくに形状記憶合金 の特異な変形挙動はせん断応力が重要な支配因子である ことを述べた。これを踏まえ，形状記憶合金研究におけ る一般負荷の重要性を，ここで少し詳細に説明したい.

形状記憶合金のいわゆる形状記憶メカニズムはオース テナイトーマルテンサイト間の相変態である.つまり結 晶構造が変化することの利用である. この相変態は, 温 度および応力によって制御される. すなわち, 形状記憶 効果は, 温度誘起マルテンサイト変態（およびその逆変 態）と応力誘起マルテンサイト変態（およびその逆変 態) の組み合わせにより生じる.この変態の結晶学的詳 細は，極めて複雑であるのでここでは，その基本メカニ ズムに通常用いられる模式図を用いて説明を進めていく. Fig. 1 の正方格子を母相（オーステナイト相）であると する.これを冷却すると, Fig. 1(a)に示したような双晶 型変態 (マルテンサイト恋態 : 結晶構造の変化) が生じ る.この冷却による変態は一般に方向性がなくランダム に生じるため, わずかな体積変化が見られるものの, 大 きなゆがみ（変形，あるいは形状変化）は観察されない. 加熱すると元の母相に戻る. 一方, このような母相構造 にせん断応力が加わるとこの双晶型変態（マルテンサイ 卜変態）は，(せん断応力の方向と関連した）一つの方 向にそろって生じる.つまりここでは大きな永久ゆがみ （永久形状変化）が発生する．しかもこのゆがみ（変形） は, 限界はあるものの数\%に達し, 弾性変形, あるいは 熱弾性ひずみに比べて極めて大きい.このゆがみは, 加 熱による逆変態（オーステナイト変態）により元に戻る. この様子を, 応力ーひずみ関係で示すと Fig. 1 (c)（実線） となる.すなわちこれがいわゆる典型的な形状記憶現象 (効果) である. また, Fig. 1(b)において, 実験室温度 がオーステナイト (逆) 変態温度よりも高い場合, 除荷 の途中からオーステナイト変態 (逆変態) が生じ, 加熱 しなくても変形は元に戻る (Fig. 1 (c) 破線).これは, 擬弾性変形現象（あるいは擬弾性効果）と呼ばれる。そ



Austenite

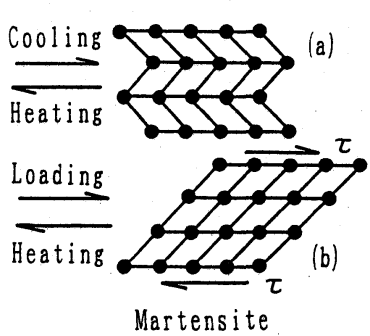

Martensite



Fig. 1. Temperature-induced and stress-induced martensitic phase transformations. 
のメカニズムは，形状記憶効果とまったく同じであり， 環境の違いにより現れる巨視的挙動の見かけ上の違いで ある。

さて，ここで温度はスカラー・パラメータ（独立変数 は 1 ）に対し，前節で指摘したように応力は 2 階のテン ソルであり 6 つの独立の成分を持つ。すなわち変態の大 きさと方向を $6 つ の$ 独立成分を変化させることによりコ ントロールできる可能性がある，つまり，現在の形状記 憶合金の応用は，極めて単純な負荷（単純ねじり，単軸 引張り，あるいは組合せ比例負荷）の範囲に限られてい

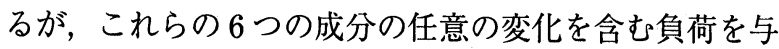
える時, 形状記憶合金には極めて多様で複雑な, しかも 所要の変形挙動を発生させることができるはずである. 形状記憶合金に単純な伸び・縮みを与えるだけでなく， 3 次元的な複雑な動き・変形・力を与える. また制御で きる可能性がある.

次に, 工学的応用で用いられる形状記憶合金のほとん どは多結晶体であることに注目しょう．多結晶金属はそ の名のとおり，多数 (無数) のミクロンオーダーの成分 結晶粒より成っている. しかもこれらの結晶粒はそれぞ れ勝手な（ランダムな）配向を持っている。ここで言う 配向とは，結晶学的に決まる双晶を生じやすい面と方向 の組で表されるいわゆる双晶系が空間的にどのように配 置されているかである．著者らの実験に採用した銅系形 状記憶合金では一つの結晶粒内に 24 の等価な双晶系が ある.すなわち，各結晶粒成分は相変態に関し強い異方 性を持つ.このような, 異方性を持つ結晶粒が多数集 まった多結晶体に負荷が加わった場合，これら配向の異 なる結晶粒間の相互干渉のためいわゆる内部応力（結晶 粒間の応力差), また残留応力 (除荷後にも残留する微 視的応力:これらのトータルは外力とつりあうためゼロ である）が発生する。すすなわち，外的に与えられた荷重 が極めて単純なものであっても，各成分結晶粒には，そ れぞれ互いに異なる複雑な複合負荷が加わることになる. 今, この残留応力を例にとって結晶粒間の相互作用の影 響の効果について考えてみよう. Fig. 2 はこのための説 明図である．残留応力に対応するような，外力に比べ極 めて小さな応力が結晶粒に加っている場合を考えてみよ う.この時母相（オーステナイト結晶構造）は, その小 さな応力分だけ弾性的にゆがんでいる.これが Fig. $2(\mathrm{~b})$ の状況である.これを冷却するとどのようになるか.こ の応力が極めて小さいものであっても, マルテンサイト 変態はこの負荷方向に導かれ大きな変形（ゆがみ）を生 じる (Fig. $2(\mathrm{c})$ ). Fig. 1 で説明した温度変化のみでは相 変態は生じても，大きなゆがみ（変形）は得られない状 況を思い出して頂きたい. たとえ, 残留応力が応力誘起 マルテンサイト変態応力よりもはるかに小さくても, 形 状記憶合金の変形に対し決定的な役割を果たす．実際の 現象とのかかわりを挙げれば，例えば次のようである. 形状記憶合金は，負荷-除荷-加熱でその形状が元に戻る のがその特徵であるが，多結晶形状記憶合金では，一般 にそのプロセスを何度か繰返すことによりその特性を獲
得できる. いわゆる形状記憶効果の安定化 (STABILIZATION) である.これは上記の内部応力 あるいは残留応力が支配パラメータであると考えられる. また，形状記憶合金をロボットなどのためのアクチュエ 一タとして用いる場合，重要な問題として形状記憶合金 のトレーニングがある. すなわち, 適当な残留（内部） 応力を材料あるいは構造要素に発達させることにより， いかなる外的負荷も加えることなく, 温度を繰返し変動 させるだけで，形状記憶合金に繰返し変形，あるいは繰 返し力を発生させようとするものである（2 方向形状記 憶効果の付与). このような, 形状記憶合金のトレーニ ングによるいわゆるアクチュエータ機能付与は形状記憶 効果の工学・工業的応用の観点から極めて重要な研究課 題となっている.

さて，上述のような形状記憶合金の微視的構造・微視 的変形メカニズムを考える時, 形状記憶合金の複雑な挙 動に対し予測性を持つ構成方程式を形式化するためには, 成分結晶粒に生じる内部（残留）応力あるいは内部（残 留）ひずみを考慮する必要がある。いわゆる，メゾスコ ピック・アプローチが必要な領域である。この種の材料 不均一を扱うため, 塑性力学などの分野ですでにいくつ かのモデルが提案されている. 結晶粒成分の力学的特性 については，いわゆる結晶塑性論に基づきモデル化され， それら結晶粒間の相互作用（これによって生み出される 内部応力, 内部ひずみ）は，いわゆるセルフ・コンシス テント・タイプのモデルにより取り入れることができる. このような多結晶体の塑性力学的モデル構築のためのメ ゾスコピック・アプローチの詳細については, 著者の論 文・解説もあるので参照して頂ければ大変幸いである。

形状記憶合金の力学的变形挙動に関する構成方程式の 提案については, 単軸負荷・除荷条件下のものがほとん どである. とくに熱力学的考察に基づくMuller のもの, 田中らによるものが受け入れられている。また, 多軸一 般負荷条件については, 例えば, Sun Q. P. 5, Patoor -Berveiller, Ranieckie, 田中らによってその構築が進 められている. そのうちいくつかはメゾスコピックなア プローチに基礎を置いている：しかしながら，これらの 構成方程式で得られた結果について, 多軸負荷の実験結 果の検証を受けていない.これは, 多軸負荷実験結果が ほとんど見当たらないためである．最近いくつかの研究 室で多軸負荷実験の準備が進められて来ていると聞くが,



Fig. 2. Effect of residual stress. 
少なくとも国際会議録などで公表されたものとしては, 著者らのグループによるもの以外には見当らない。この ような多軸研究の遅れには, もちろんいくつかの理由が ある. まず，マルテンサイト変態にかかわるこのような 力学現象につき機械工学の研究者・技術者が興味を持ち 始めたのが，ほんの，ここ 10 年程度にすぎず，極めて 歴史の浅いことが挙げられる。 また，その形状記憶特性 が最も優れ，研究開発およびその応用が最も活発である いわゆる $\mathrm{Ti}-\mathrm{Ni}$ 系形状記憶合金注，線材としては提供 されるが，バルク材料の製造は極めて難しい。したがっ て，例えば巨視的な多軸負荷実験法のスタンダードであ る, 薄肉円筒試験片あるいは 2 軸引張薄板試験片などを 用意することが極めて困難である．この状況にあって， ごく最近 Ti-Ni 形状記憶合金コイルばねの変形特性を 解析することにより，組合せ応力効果の基本特性を究明 する試みが発表さされている。これは， Ni-Ti 形状記憶 合金における上記の問題を回避するひとつの興味ある手 法であるが，新たな問題を生むことにもなる．最近，よ うやく加工性に優れ，かつ値段が比較的安い銅系形状記 憶合金や鉄系形状記憶合金にも興味が向けられるように なってきた，これら鉄系，および銅系形状記憶合金は， その形状記憶特性，また疲労特性においては劣るものの， 線材に限られる $\mathrm{Ti}-\mathrm{Ni}$ 系合金に対し，比較的容易にバ ルクなものを製造することができ，形状記憶効果の新た な応用性拡大が期待できる．基礎実験観点からすれば通 常の旋盤加工で例えば薄肉円管試験片を作成することが でき，これらの材料をサンプルとして，複合負荷に対す る形状記憶合金の熱-力学特性を調べることができる.

以下に，著者らの銅系形状記憶多結晶金属を用いた実 験結果を例に引きながら一般負荷条件下における形状記 憶合金の変形特性を紹介する。

\section{3 複合負荷条件下の実験結果の紹介}

\section{$3 \cdot 1$ 試験片および実験方法}

用いられた試験片は，銅系形状記憶合金 $\mathrm{Cu}-10 \mathrm{wt} \%$ Al-5 wt \% Mn-5 wt \% Zn で作られた外径 $8 \mathrm{~mm}$, 内径 $5 \mathrm{~mm}$, ゲージ長さ $40 \mathrm{~mm}$ の薄肉円管である. 熱処理 により無負荷状態における基本变態温度は

$M_{s}=239 \mathrm{~K}, M_{f}=223 \mathrm{~K}, A_{s}=248 \mathrm{~K}, A_{f}=260 \mathrm{~K}$ に調質してある.したがって用いたこの試験片材料は室 （常）温において擬弾性挙動を示す。ここに $M, A$ はマ ルテンサイト, オーステナイト, 下添字 $s, f$ は開始扔 よび終了を意味する，試験機には島津オートグラフ AG10TC を用いた。この試験機により, 薄肉円管試験 片に軸応力 $\sigma$ (あるいは軸ひずみ $\varepsilon$ ) とねじり応力 $\tau$ （あるいはねじりひずみ $\gamma$ ）を同時に加え，かつ独立に 制御することができる. 温度 $T$ は電気炉により变動さ せることができる.

実験はこの装置を用いて, 応力-温度空間 $\left(\sigma, C_{1} \tau\right.$, $T)$ ， あるいはひずみ-温度空間 $\left(\varepsilon, C_{2} \gamma, T\right)$ にて種 々の経路を与えることにより行われた．ここに， $C_{1}$ と $C_{2}$ は温度一定 (室温)下におけるねじり試験と引張試 験の応力ーひずみ関係を一致するように導入した係数で
ある. 同時にこれらの係数を用いることと, 温度一定下 における種々の比例負荷試験により得られる相当応力 $\left(=\left[\sigma^{2}+\left(C_{1} \tau\right)^{2}\right]^{1 / 2}\right)$-相当ひずみ $\left(=\left[\varepsilon^{2}+\left(C_{2} \gamma\right)^{2}\right]^{1 / 2}\right)$ 関 係も引張試験のそれに一致させることができる.

\section{$3 \cdot 2$ 単純負荷試験結果}

Fig. 3 は, 常温下における単軸引張一除荷繰返し試験 の結果を示している. Fig. 3(a) からわかるように擬弾性 変形が安定化するには 10 回程度の繰返し予変形を与え ることが必要である. また, 安定化した後の部分ループ 実験の結果を Fig. 3 (b)〜(d) に示した. 近年，ようやく この部分ループの詳細を通じての多結晶形状記憶合金の メカニズムの研究，およびその形式化が研究されるよう になっている゙. これらの図からわかるように，一般に銅 系形状記憶合金の擬弾性ループの面積（エネルギー消 散）は Ni-Ti 系合金のそれに比較して小さく（使い方 にもよるが）形状記憶機能としては劣っていると言える. またここでは，単結晶に見られるような変態にかかわる シャープな変化は見られない，この理由のひとつとして， 多結晶体の不均一性（成分結晶粒の配向，また製造過程 に扔ける何らかの不均一）を挙げる事ができる. 配向に よる材料不均一にかかわる単純負荷での応力ーひずみ関 係のスムース化は, 簡単な数理モデルによるシミュレー ション計算で確認している.

Fig. 4 は，円筒のねじり-逆ねじり繰返し試験により 得られたせん断応力一せん断ひずみ関係を示している.

図から, 両振繰返し変形を与える場合, 片振繰返し変形 の場合よりも早く安定化 (STABILIZED) サイクルが 得られることがわかる. また塑性変形に見られる様な強 いバウシンガー効果が見られないことなどが興味深い.

これは，同じ消散を伴う非弾性変形ではあるが，すべり 変形により得られる塑性変形と, 変態により得られる擬 弾性変形の違いとして理解できる。

\section{$3 \cdot 3$ 組合せ比例負荷試験}

Fig. 5 は，ねじりと軸力による比例負荷試験の結果の 一例を示している。 ここに縦軸, および横軸は, $3 \cdot 1$ 節で説明した相当応力 $\sigma_{e q}$, 相当ひずみ $\varepsilon_{e q}$ である. 組 合せ比例負荷の場合も, 単純負荷に比べて安定サイクル に達するまでのサイクル数はやや多いものの, 20 サイ クル程度で安定サイクルに達することがわかる. また, 組合わせ負荷の場合においても擬弾性特性すなわち, 無 負荷状態に対して無応力状態が対応することが確認され る. また相当応力 $\sigma_{e q}$, 相当ひずみ $\varepsilon_{e q}$ で表されたこの 安定サイクルは, 単軸引張試験により得られる安定化応 カーひずみサイクル関係にほぼ一致している．著者等の 実験によれば，これ以外の種々の応力比による比例負荷 試験の安定化相当応力-相当ひずみ関係も単軸引張りに よるそれに一致する.

\section{$3 \cdot 4$ 温度変動を含む組合せ比例負荷試験}

Fig. 6 (a) は, 与えられた温度一応力複合経路を示して いる. この場合, 点 $1 \rightarrow$ 点 2 は常温での比例負荷試験, 点 $2 \rightarrow$ 点 $3 \rightarrow$ 点 4 は応力状態を一定に保持したままで温 度サイクルを与えたことを示している．また, 点 $4 \rightarrow$ 点 

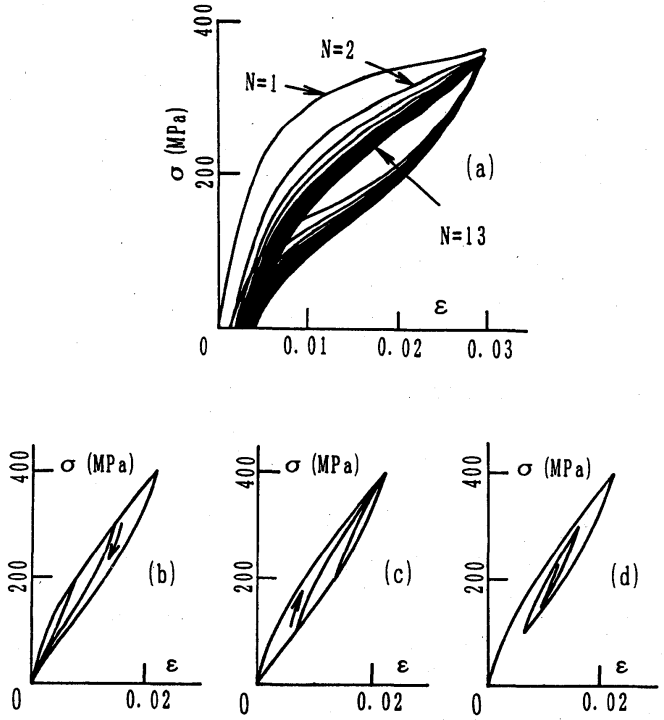

Fig. 3. Cyclic tensile loading-unloading experiments.

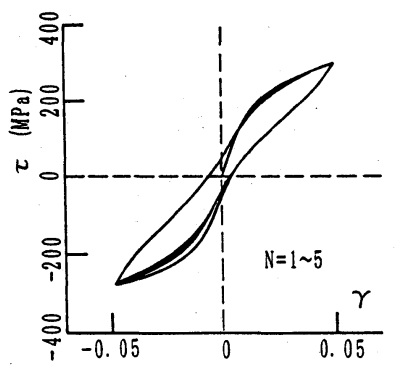

Fig. 4. Cyclic torsional experiments.
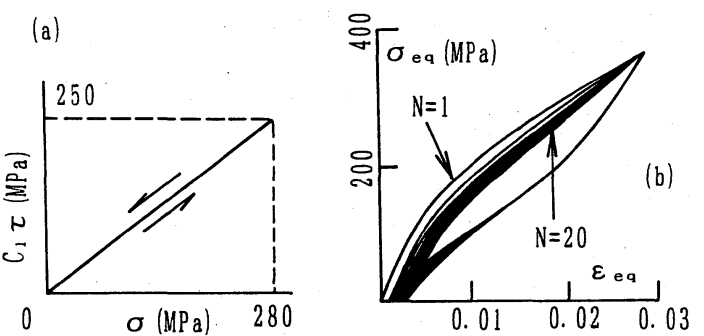

Fig. 5. Proportional loading experiment

5 は，比例的に除荷を行ったことを示している．Fig. 6 (b) は，これに対するひずみ応答を示している.ここに おいても確認されるように，比例負荷に対しては，比例 変形が対応する.また，比例負荷を与えられた状態で， 温度変化が与えられると比例変形し，かつ温度が元に戻 ると変形も元に戻る (点 4 と点 2 ). 寸なわち, 試験片 の形状は記憶されている。 したがって, 負荷点 2 で複数 回の温度サイクルが与えられると, 変形応答 $2-3-4$ が繰返されることになる. 少しくどくなるが，このよう な方法で，形状記憶合金に 2 次元的挙動を与えることが 可能となる. 寸なわち，温度変化を与えることにより， ねじれと伸縮を同時にかつ比例的に発生させることがで きる。

Fig. 7 は，温度変動を持つ比例負荷試験の別の例を示
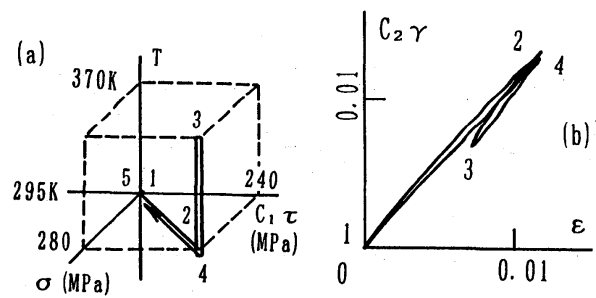

Fig. 6. Proportional loading experiment with temperature change (I).
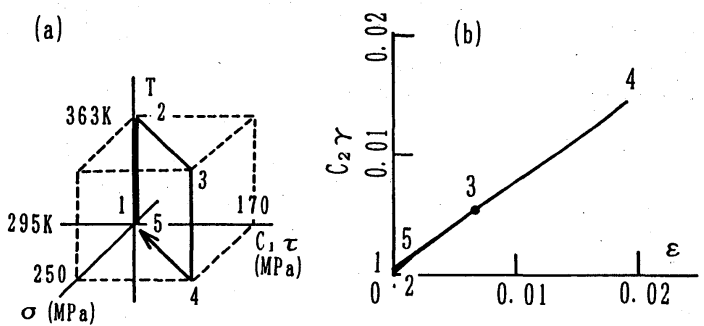

Fig. 7. Proportional loading experiment with Temperature change (II).

している．この場合，まず温度を上昇させてから行った ものである．形状記憶合金の当然の特性ではあるが，温 度を下げる (Fig. 7 (a)での点 $3 \rightarrow$ 点 4 ) 事により，大き な変形の比例的增加 (Fig. 7 (b) での点 $3 \rightarrow$ 点 4 ) を得る ことができる．また，この場合でもゼロ応力状態は，ゼ ロひずみ状態に対応している，すなわち，このようにや や複雑な経路をたどる場合でも形状記憶合金はその元の 形状は記憶している.

\section{$3 \cdot 5$ 複合負荷試験}

次に複合変形および複合負荷試験結果の一例を示す. 複合負荷（変形）試験とは，ここでは応力（あるいはひ ずみ）空間においてその経路が直線的でない（比例負荷， あるいは比例変形的でない）場合を総称する。この複合 負荷には， 2 軸引張試験で与えられる様な応力テンソル （あるいはひずみテンソル）の主軸不変な場合と，本論 文で扱う様な引張りとねじりの組合せ負荷が与えられ， 主軸が回転する場合の 2 種類がある．変形中の活性化バ リアントの変化を考える時，形状記憶合金の巨視的変形 挙動の理解に対していずれの実験も必要であるが， 2 軸 引張試験は，いずれの研究室でも，まだ行われておらず （あるいは公表されて扮らず）残念ながら論評できない.

さて, Fig. 8 は複合変形試験の一例として, 三角形形 状複合ひずみ経路（OABO，OCBO，OBAO，OBCO） に対する応力応答を示したものである。ここで注目すべ き特徴のひとつは, 経路 $\mathrm{OAB}$ と経路 OCB をたどった 後生じた応力状態 $\mathrm{B}^{*}$ と $\mathrm{B}^{* *}$ の違いである.すなわち, 塑性変形と同じく, 同じ変形状態であっても，そこに至 る変形経路が異なる場合, 到達される応力状態は異なる. すなわち明瞭な履歴（経路）依存性が観察されている.

更に興味深いことは，無ひずみ状態は常に無応力状態に 対応し，履歷依存性が消滅している，形状記憶合金の変 形メカニズムからすれば当然のことであるが, 弾性変形, 塑性変形になじんできている従来の固体力学研究者に 


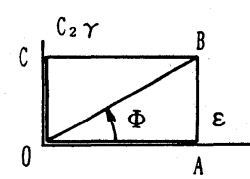

(a)

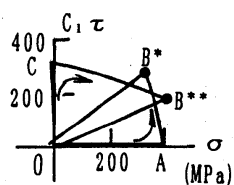

(b)

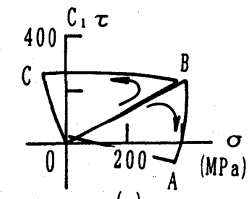

(c)
Fig. 8. Complex deformation experiment $(\mathrm{OB}=3.0$ $\%, \Phi=36^{\circ}$ )

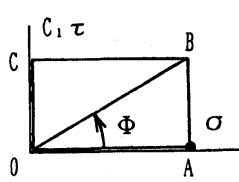

(a)



(b)

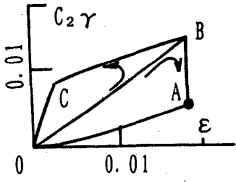

(c)
Fig. 9. Complex loading experiment $(\mathrm{OB}=350$ $\mathrm{MPa}, \Phi=36^{\circ}$ ).

とっては極めて新鮮な現象に見える.Fig. 9 は複合負荷 試験の一例を示している. Fig. 8 に示したひずみ制御の 実験とは異なり, 応力制御で三角形状複合応力閉経路 OABO，OCBO，OBAO，OBCO [Fig.9(a)] を与えた 場合である．対応するひずみ応答を Fig. 9 (b)，(c) に示 した。ここでも明らかに履歴依存性が認められる。すな わち，Fig. 9(b)におけるひずみ状態 $\mathrm{B}^{*}$ と $\mathrm{B}^{* *}$ は，いず れも同じ応力状態点 $\mathrm{B}$ に対応している.このような履 歴依存性の発生の根拠は, 例えば単軸引張応力ーひずみ 関係から推定することができる.すなわち，単軸引張り の応力ーひずみ関係の概略図 Fig. 10 において，例えば応 力 $\mathrm{A}$ に対して，2つのひずみ $\mathrm{B}$ と $\mathrm{C}$ が対応する。 また ひずみ $A^{*}$ に対して応力 $B^{*} と C^{*}$ が対応する。.このよ うなエネルギ消散に伴う変形挙動の多様性が，複合負荷 条件下ではさらに複雑な形で現れることになる．この複 雑さを生み出すのは, 例えば変形中の応力主軸の回転 （単軸引張り，あるいは比例負荷試験では応力主軸の回 転はない）に伴う活性バリアントの変化などが考えられ る.このような履歴依存性は，とくに一般負荷条件下に おける形状記憶合金の精度の高い構成方程式の形式化を 極めて困難なものにする，履歴依存性については，良く 知られるように塑性変形において見られ；塑性異方性の 発達のメカニズムの解明あるいはこれを考慮した信頼性 の高い構成方程式の構築に関連して研究者の興味を長い 間引きつけていた。この経験は，形状記憶合金の構成方 程式形式化に対し多くの示唆を含んでいるが，その微視 的変形メカニズムはまったく異なることを留意しなけれ ばならない.いずれにしても，この研究は始まったばか りである. Fig. 9(c)にもう一つの興味深い現象が見られ る. 経路 OBAO (Fig. 9 (a)) に対する応力応答 OBAO (Fig. 9 (c)）に注目されたい. 応力点 A では，すでにせ ん断応力はゼロである，一方，対応するひずみ状態点 $\mathrm{A}$ では，せん断ひずみ成分が残っている。この残留せ ん断ひずみ成分は，軸応力の除荷（Fig. 9(a)のAO）に よって，軸ひずみと同時に消滅する。すなわち，これは 軸応力を変化させることにより，大きなせん断ひずみ



Fig. 10. Simple case of path dependency.

（円筒の場合，ねじり変形）の変化を与え得ることを意 味する. 応力経路 CO (Fig. 9(a)) に対応する応力応答 CO (Fig. 9 (c)) からわかるように, この逆も真であり, せん断応力の除去により軸ひずみが消滅する。このよう な特性は形状記憶合金の工業的応用の拡大を感じさせて くれる.

\section{$3 \cdot 6$ 温度変動を伴う複合負荷}

Fig. 11 に温度変動を伴う複合負荷試験の一例を示す. Fig. 11 (a) は用いられた温度-応力履歴経路であり，(b) は対応するひずみ応答経路を示している. Fig. 11 (b) に おいて, 1-2: 軸応力負荷, $2-3$ : せん断応力負荷, $3-4$ : 応力状態を維持したまま温度を室温から $363 \mathrm{~K}$ まで上昇させる，4-5: 温度を保ったまません断応力 を除荷する，5-6: 軸応力を除荷する， 6-7:温度 を室温に戻す，である。温度を変動させた状況に注目し てみよう．温度上昇 3 - 4 に対し，ひずみは原点（ひず みゼロ）に向かって $3-4$ とほほ比例的に大きく減少す る（ただし，厳密には原点 0 と点 3 を結ぶ直線上にある わけではない.この理由は次に示す実験結果から理解で きる).また，Fig. 11 に示された破線は，前述の経路か ら温度変動を除いた場合を示している。この図から負荷 経路 1-2-3 と除荷経路 3-2-1では, 対応するひ ずみ応答は互いに異なっていることが確認できる。また， この応答経路と, 温度変化を含む経路では, 応力の変化 は同じであるが，その応答経路には大きな違いが出てい る. すなわち, 複合負荷経路に加えて, これに適当な温 度変化を与えることで, 形状記憶合金に極めて多様で複 雑な多次元挙動を与え得ることを示唆している. 本実験 を例に取れば，例えば，温度変化量を変えてやればひず み応答 $3-4$ 間の距離を変えることができる.

Fig. 12 は，温度変動を含む複合負荷試験のもうひと つの例を示している. 温度一負荷経路は Fig. 12 (a) に示 すように，1-2: 軸応力とせん断応力の組合せ比例負 荷， 2-3-4 : 応力状態を維持したまま温度を上下さ せる，4-5: せん断応力の除荷, 5-6-7 : 応力状 態を維持したまま再び温度を上下させる， 7-8: 軸応 力の除荷，である．対応するひずみ応答経路は Fig. 12 (b)に示した．温度変動を与えた場合に注目してみよう。 まず，比例負荷の後，温度を上下させた場合（2-34 ), すでに観察・議論したように, 温度上昇に対し逆 変態が生じ，比例的に変形は減少する. 温度を元に戻す （低くする）と，再度マルテンサイト変態が生じ，ひず 

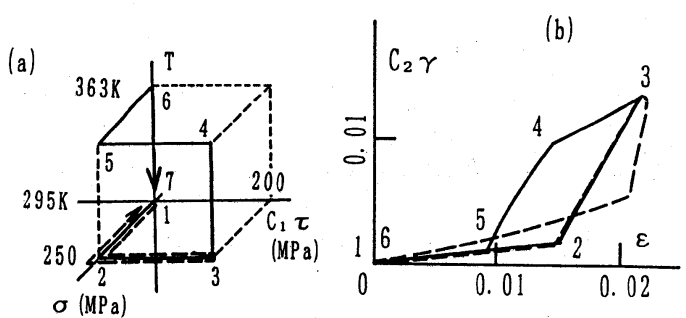

Fig. 11. Complex loading experiment with temperature change (I).


Fig. 12. Complex loading experiment with temperature change (II).

みは比例的に上昇し，元の点 $(2$ と 4$)$ に戻る.すなわ ち形状記憶合金は温度変化の前の変形状態を記憶してい ることになる. また，この温度変化を繰返すことは，こ の薄肉円筒試験片に軸方向の伸びとねじれ変形を同時に 比例的に繰返し与えることを意味する。ここまでは,

Fig. 6 に示した比例変形試験結果と同じである. 次に温 度変化経路 5-6-7 に対するひずみ応答 5-6-7 （Fig. 12 (b)）を見てみよう。この場合, 応力状態 5 は複 合負荷（応力主軸の回転を含む負荷）プロセスの結果と して到達された状態である (応力状態 2 は, 組合せ負荷 により得られたものであるが，比例負荷プロセスにより 到達されたものであり, 応力主軸の回転は含まれていな い).この場合, 温度を上昇させると, ひずみは必ずし も比例変形的でない形で減少する $(5-6)$. また，そ の後温度を上昇させると，ひずみは増加するが元のひず み状態 5 ではなく点 7 にたどりついている.すなわち, この場合, 比例変形で与えられた点 2 の変形状態と異な り, 複合負荷で得られた点 5 の変形状態は, 記憶されて いない.すなわち, 温度を元に戻しても変形は元に戻ら ない. 形状記憶合金もその形状を記憶していないことが あることを記憶すべきである。

\section{4 形状記憶合金の力学的モデルと構成方程式} について

3 章で示したのは, 複合負荷条件とはいえ, 熱力学的 にも, 運動学的にも，金属物理学的にも, 力学的にも極 めて限られた条件内の結果であり，実際の形状記憶合金 の挙動はさらに多様である. しかしながら工学的応用を 考える時, ある限られた条件下での挙動の正確な信頼性 の高い予測が極めて重要であることも確かである。ここ では，このような意味を背景に，3 章で示した実験事実 を再現でき，さらにある程度の予測性を持つ構成方程式 の形式化手法の一例を示す.

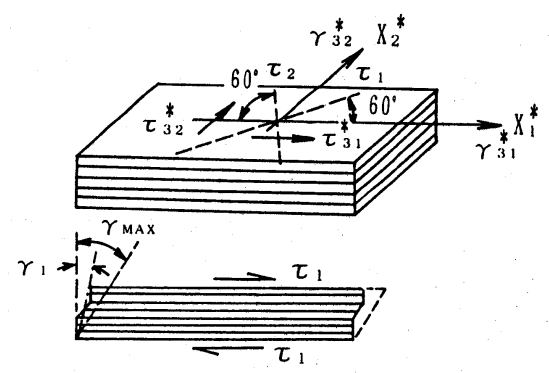

Fig. 13. Two-dimensional model of single crystal component.

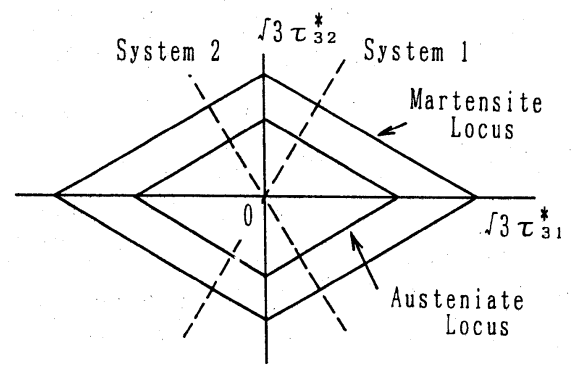

Fig. 14. Phase Transformation surfaces.

さて，ここでは構成式の形式化に当たって次のような 基本的仮定を置いている (モデル化している).

（1）応力誘起相変態は正，逆とも双晶変形システムに 対する分解せん断応力がある一定值（臨界せん断応力） になった時に開始する.

（2）臨界せん断応力は，マルテンサイト変態に対して もオーステナイト変態（逆変態）に対しても, 温度上昇 に比例して増加し，変態により生じたせん断ひずみの総 和に比例して増加する.

（3） 結晶粒間の相互作用は，セルフ・コンシステント モデルあるいはそれに類似（あるいは準じる）モデルに よって考慮する。

さて以上の基本的仮定の下で， 3 章で示された種々の 実験結果の再現を試みる。ただし, 計算の簡単のため, 次のような 2 次元結晶モデルを採用する，すなわち，こ の結晶はちょうど重ねられたトランプ・カードのように すべる（せん断変形する）ことができる．そして，この トランプカードに面内せん断応力を加えると当然のこと ながらカードは “ずれ（せん断ひずみ $\gamma$ ）”を生み出す.

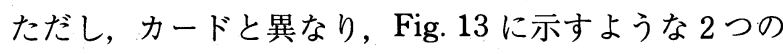
方向にのみせん断変形するものとする（破線 : $\mathrm{X}_{1}^{*}$ 軸か ら $60^{\circ}$ あるいは $120^{\circ}$ 回転した方向)。また, 塑性変形の すべりと異なり，このせん断変形の大きさにはある限界 があるとする $\left(\gamma \leqq \gamma_{\max }\right)$. この制限は，形状記憶合金の 変形メカニズムが双晶型変態であり，この恋態が完了し た時点でそれ以上の非弾性せん断ひずみは生じないこと により付加される.この時, この結晶モデルの変態面は Fig. 14 に示すように 2 次元せん断応力平面 $\left(\sqrt{3} \tau_{31}^{*}\right.$, $\left.\sqrt{3} \tau_{32}^{*}\right)$ に扔いて 2 つ菱形で表される. 外側はマル テンサイト変態開始面であり，内側の菱形はオーステナ イト変態（逆変態）開始面である，仮定に従って，これ 
らの菱形は, せん断変形の増加・減少に対し, また, 温 度の上昇・下降に対し相似拡大・縮小する.さててこの ような力学特性を持つ 2 次元結晶粒が多数集まって多結 晶体を形成し, 巨視的せん断応力負荷 $\left(\sqrt{3} \tau_{31}\right.$, $\left.\sqrt{3} \tau_{32}\right)$ が与えられた場合，各結晶粒ではその配向によ り, それぞれ異なる挙動を示すが, これらの平均として 多結晶体の変形挙動が算出される.

Fig. 15，16 は, この力学モデルにより算出された形 状記憶合金の変形挙動の一例を示す， 3 章に示した実験 結果との比較においては, $\sqrt{3} \tau_{31}=\sigma, \sqrt{3} \tau_{32}=C_{1} \tau$, $\gamma_{31} / \sqrt{3}=\varepsilon, \gamma_{32} / \sqrt{3}=C_{2} \gamma$ なる対応があることに留意 されたい.この対応に関する理論的根拠は数理塑性論に て発展させられ，とくにイリューシの一般塑性理論で論 じられた 2 階対称テンソルに関する一般関係に基づくも のである゙．ただし，用いた対応は，材料挙動が，主とし て応力（あるいはひずみ）テンソルの第 2 不変量に支配 され，第 1 および第 3 不変量の影響は無視できるという 仮定に基ついている。この対応は，多結晶体の塑性変形 に対しては有効であったが（第 1 および第 3 不変量の効 果が小さいので), 形状記憶合金の場合, これら $2 つ の$ 不変量の影響はいまだ必ずしも明確ではなく，これから の研究課題である.ここにおいて, 係数 $C_{1}, C_{2}$ の導入 について，理論的には極めてあいまいなものがあること を認めなければならない，同時に，実際の実験では，特 にねじりが入った場合円筒が有限の厚みを持っているた め，変形は必ずしも一様でないこと，また材料が初期状 態において初期等方性が保たれているかどうかの問題な どもある.いずれにしても，多くの問題を含んでいるが， 研究は始まったばかりである。

さて Fig. 15 は，応力制御で行われた 3 角形応力負荷 閉経路（Fig. 9 に示した実験結果に対応）に対する計算 結果を示す．また Fig. 16 は，3 角形複合応力経路にお いて温度サイクルを負荷した場合 (Fig. 11 に示した実 験結果に対応）に対する計算結果を示している．モデル の簡単さのため定量的には十分ではないが，複合負荷条 件下に見られる形状記憶合金の変形挙動の傾向を良く再 現していると考えられる.

なお，ここでは計算の簡単のため, 結晶粒間の相互作 用については，応力一定（マクスウェル型）の仮定を用 いて考慮した：この他，良く知られているように，ひず み一定（ホイクト，あるいは T. H. Lin 型）の仮定，あ るいはより理論的なセルフコンシステント・モデルの採 用も考えられる：著者らの経験によれば，これらのモデ ルの間には, 確かに単軸引張りの応力ーひずみ関係にて 定量的な差を生み出すが，定性的には大きな差異はなく， この定量的な差は工学部的観点からすれば材料定数の選 択でカバーできる．複合負荷においても，その定性的特 徵は，いずれのモデルを用いても大差はない.もちろん より精密なセルフコンシステント・モデル使用が最も望 ましいが，決定的な問題にはならないと著者は判断して いる. また，このセルフコンシステント・モデルももち ろんパーフェクトなものではなく, 結晶粒界の特性, 結
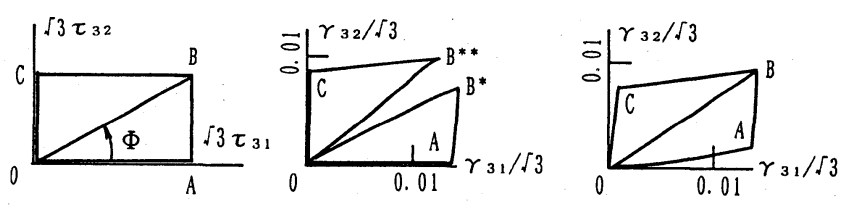

Fig. 15. Computer simulation result (I).

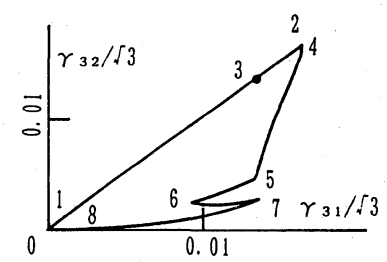

Fig. 16. Computer simulation result (II).

晶粒の形状，結晶粒内のひずみ抢よび応力不均一の影響， などを無視している点から多くの改良の余地がある。な お塑性力学研究の分野では, Hill の厳密理論, あるいは セルフ・コンシステント・モデルの修年を試みたもの, あるいは有限要素法の発達を基礎にし, 微視的不均一を より精密に取り入れる高橋らの試みも見られている。こ れらは, 工学における微視的メカニズム, 微視的材料構 造の取り入れの難しさを示していると同時に,メゾメカ ニクスの工学における役割と期待を感じさせてくれる.

\section{5 おわりに}

本稿では, 複合負荷条件下における形状記憶合金の研 究の意義と, 現状について紹介した。ここで明らかにし た事は, 研究は始まったばかりであり, 研究手法自体も まだ確立されておらず模索の状態ということである. 形 状記憶現象の基本メカニズム（温度誘起マルテンサイト 変態および応力誘起マルテンサイト変態）自体について は, これまで多くの基礎的・物性学的あるいは金属学的 分野での研究の膨大な蓄積があり, こここに得られている 知見を十分に生かす事が大切であり，機械工学と金属・ 材料工学との境界・融合領域である:

最後に, 形状記憶合金, あるいは形状記憶効果の研究 に対する期待を記しておきたい.

まえがきにも触れたが, 複合材料, 機能材料に続き理 想材料として知能材料の概念がある. これは, 特に大型 構造物や, 航空機, 人工衛星・宇宙往還機・宇宙ステー ション, また, 原子力機器などそのメインテナンスの困 難な機器・構造物用材料のための理想材料として期待さ れており, 多くの研究活動, 研究会活動, 国内・国際会 議の開催などが近年極めて活発である.ここにおいて， 形状記憶合金は, 圧電素子などと並んで大きな期待を集 めている.

また，次世代ロボットのアクチュエータとして人工筋 肉の概念の提案とその具体的研究開発の活動がある.こ こでは, 低位のエネルギーを有効な力学的エネルギーに 変換する素子の開発であるが,ここでも圧電素子・圧電 ゴム (電気エネルギ↔力学エネルギ), 高分子ゲル (化 学エネルギーーカ学エネルギ), などと並んで形状記憶 


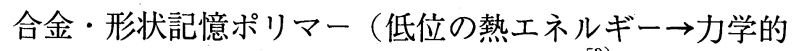
エネルギー）に対する興味・期待は大きい、，材料自体が その構造を維持できるアクチュエータということはいく らでも小さいモー夕を作ることができることを意味し， マイクロマシン的価值観・評価も可能である.もちろん, すでに工業的応用が進められている周知の分野もある. 基礎的には相変態にかかわる極めて力学的な興味ある現 象として，また応用的には従来の大エネルギー・高効率 型工学技術に対し, 低エネルギー・低効率工学技術ある いは環境適応・人間適応工学技術としての価値観からこ の研究の価值を眺めてみるとまた興味深いものがある.

また，原点に戻ってこの応力誘起相変態により生じる 大きな非弾性変形，あるいはこれにかかわるエネルギー 消費（消散）を利用した構造材料のじん性向上の試みと 評価，また形状記憶粒子による材料強化なども活発に研 究されている.

若き読者に, 材料研究, 相変態研究, 形状記憶効果研 究に対する興味を少しでも持っていただければ著者に とって望外の幸せである。

\section{参 考 文 献}

1) T. Inoue and T. Ohomori, Proc. of 1st Int. Seminor on Microstructure, and Mebhanical Properties of New Eng. Mat., p. 515 (1993) Mie Academic Press.

2 ）上原拓也, 井上達雄, 材料, 44, 309 (1995).

3 ) P. Sittner, K. Hara and M. Tokuda, Proc. of Int. Seminor on Microstructure, and Mechanical Properties of New Eng. Mat., p. 57 (1993) Mie Academic Press.

4 ) P. Sittner and M. Tokuda, Advanced Materials '93, Trans. Mat. Res. Soc. Jpn, 18B, 951 (1994).

5 ) P. Sittner, Y. Hara and M. Tokuda, Proc. of ICSMA 10, p. 319 (1994).

6 ) P. Sittner and M. Tokuda, Proc. of Int. Symp. on Shape Memory Mat., p. 541 (1994) Int. Academic Pub. .

7 ) P. Sittner and M. Tokuda, Proc. of 15th Riso Int. Symp. on Mat. Sci., p. 537 (1994) Riso National Lab..

8 ) 原 康治, 徳田正孝, ペトロ・シットネル, 日本機械学会 東海支部岐阜地方講演会講演論文集, No. 943-2, p. 147 (1994).

9 ) P. Sittner, Y. Hara, M. Takakura and M. Tokuda, Res. Rep. Fac. Eng., 19, 9 (1994) Mie Univ. .

10）徳田正孝, ペトロ・シットネル, 日本機械学会関西支部第 70期定時総会講演会講演論文集, No. 954-1，209（1995）.

11）徳田正孝, ペトロ・シットネル, 高倉正佳, 日本機械学会 東海支部豊橋地区講演会講演論文集, No. 953-2, 63 (1995).

12) P. Sittner, M. Takakura and M. Tokuda, Scripta Metallurgica, 32, 2073 (1995).

13) M. Tokuda, P. Sittner and Y. Hara, Proc. of 2nd Int. Seminor on Microstructure, and Mechanical Properties of New Engineering Materials, p. 427 (1995) Academic Pub. .

14) Y. Hara, P. Sittner and M. Tokuda, The Third Asian -Pacific Workshop on Intelligent Mat. \& the 4 th Symp. on Intelligent Mat., p. 28 (1995).

15) M. Tokuda, P. Sittner and M. Takakura, Proc. of the 5th Int. Symp. on Plasticity and Its Current Applications, p. 367 (1995) Gordon and Breach Pub.

16) ペトロ・シットネル, 徳田正孝, 材料, 44, 597 (1995).

17) M. Tokuda, P. Sittner and Y. Hara, Proc. of the First Asia -Oceania Int. Symp. on Plasticity, p. 88 (1993).

18）徳田正孝, ペトロ・シットネル, 原 康治, 日本機械学会 平成 5 年度材料力学部門講演会講演論文集, No. 930-73, 531 (1993).

19) M. Tokuda and P. Sittner, Proc. of 2nd Int. Symp. on Advances in Eng. Plasticity and Its Applications, p. 11 (1994) Int. Academic Pub.

20）徳田正孝, ペトロ・シットネル, 原 康治, 日本学術会議 第43回応用力学講演会講演予稿集, p. 671 (1994).

21） M. Tokuda and P. Sittner, 日本学術会議第 43 回応用力学講 演会講演予稿集, p.667 (1994).

22）徳田正孝, 原 康治, ペトロ・シットネル, 日本機械学会 東海支部岐阜地方講演会講演論文集, No. 943-2, 151 (1994).

23）徳田正孝, ペトロ・シットネル, 第44回応用力学連合講演 会講演論文集, p. 65 (1995).

24) M. Tokuda, M. Ye, Y. Hara, M. Takakura and P. Sittner, Proc. of Int. Symp. on Microsystems, Intelligent Mat. and Robots, (submitted) (1995)

25）舟久保熙康, “形状記憶合金”（1984）産業図書.

26）徳田正孝, 大野信忠, J. Kratochvil, 日本機械学会論文集, 52, 758 (1986).

27）徳田正孝, 応用数理, 5-4, 60 (1995).

28) Muller, Acta Met. Mat., 39, 263 (1991).

29) K. Tanaka, Arch Mech. 43, 239 (1991).

30) K. Tanaka, Res. Mechanica, 18, 251 (1986).

31) K. Tanaka, H. Tobushi and H. Iwanaga, Proc. of the 31 Japan Cong. on Mat. Res., p. 51 (1988).

32) Q.-P. Sun and K.-C. Hwang, J. Mech. Phys. Solids, 41, 1 (1993).

33) Q.-P. Sun and X. J. Xu, Proc. of 1st Int. Seminor on Microstructure, and Mechanical Properties of New Eng. Mat. p. 37 (1993) Mie Academic Press.

34) W.-Y. Yan, Q.-P. Sun and K.-C. Huwang, Proc. of the 2nd Asia-Pacific Symp. on Advances in Eng. Plasticity and Its Applications, p. 233 (1994) Int. Academic Press.

35) M. Berveiller, E. Patoor and M. Buisson, Journal de Physique III, C4, 387 (1991).

36) B. Raniecki, C. H. Lexcellent and K. Tanaka, Arch Mech., 44, 261 (1992).

37) B. Raniecki and O. Bruhns, Arch Mech., 43, 343 (1991).

38) K. Tanaka, D. Hasegawa, H. J. Bohm and D. F. Fischer, Mat. Sci. Res. Int., 1, 23 (1995).

39）林 萍華, 戸伏寿昭, 田中喜久昭, 伊貝 亮, 日本機械学 会論文集，A-60，660 (1994).

40）戸伏寿昭，塑性と加工，35，910（1994）.

41）三田俊裕, 三角正明, 大久保雅文, 日本機械学会論文集, A-61, 1657 (1995).

42) F. Nishimura, K. Tanaka, E. R. Oberaigner and F. D. Fisher, Proc. of the 5th Int. Symp. on Plasticity and Its 
Current Applications, p. 343 (1995) Gordon and Breach Pub. .

43）徳田正孝, 稲垣佳也, 吉田広明, 日本機械学会論文集, A-58, 1947 (1992).

44) K. Tanaka, F. Nishimura and H. Tobushi, Jour. of Intellgent Material Systems and Structures, 7, 487 (1994).

45) Y. Ohashi, M. Tokuda and H. Yamashita, J. Mech. Phys. Solids, 23, 295 (1975).

46) M. Berveiller and A. Zaoui, J. Mech. Phys. Solids, 26, 325 (1979).

47）高橋 寛, 斉藤知子, 本橋 元, 徳田正孝, 阿部武治, 日 本機械学会論文集, A-60, 1017 (1994).

48) S. Miura and H. Katoh, Mat. Sci. Res. Int., 1, 67 (1995).

49) S. Miura and H. Katoh, Proc. of 1st Int. Seminor on Microstructure, and Mechanical Properties of New Eng. Mat. p. 37 (1993) Mie Academic Press.

50) Y. Furuya, Extended Abstract of the 3rd Asia Pacific Workshop on Intelligent Mat. and 4th Symp. on Intelli- gent Mat., p. 46 (1995)

51）鈴木 誠, 日本機械学会第 2 回バイオエンジニアリングシ ンポジウム講演論文集, No. 920-7, 3 (1992).

52）鈴木 剛, 八木一夫, 佐脇 豊, 徳田正孝, 日本機械学会 72 期全国大会講演会講演論文集，No. 940-30，IV，480 (1994).

53) H. Tobushi, S. Hayashi, A. Ikai and H. Hara, Proc. of the 5th Int. Symp. on Plasticity and Its Current Applications, p. 351 (1995) Gordon and Breach Pub. .

54) T. Iwamoto and Y. Tomita, Proc. of the 5th Int. Symp. on Plasticity and Its Current Applications, p. 331 (1995) Gordon and Breach Pub. .

55) V. I. Levitas and E. Stein, Proc. of 2nd Int. Seminor on Microstructure, and Mechanical Properties of New Eng Mat. 2, 581 (1995) Int. Academic Pub.

56) T. Tsuta, M. Hasegawa and Y. Kitazaki, Proc. of the 2nd Asia-Pacific Symp. on Advances in Eng. Plasticity and Its Applications, p. 451 (1994). 